\title{
Wood identification of Japanese and Chinese wooden statues owned by the Museum of Fine Arts, Boston, USA
}

Suyako Tazuru ${ }^{1 *}$, Mechtild Mertz ${ }^{2}$,Takao Itoh ${ }^{3}$ and Junji Sugiyama ${ }^{4,5}$

\begin{abstract}
Precious cultural assets of East Asia are found worldwide and hold many important art-historical meanings, for example Buddhist statues. In this study, we conducted wood identification of Japanese and Chinese statues owned by the Museum of Fine Arts, Boston, USA. From the eight Japanese wood sculptures and one Chinese sculpture, 15 samples were collected. The anatomical features of these 15 samples were scrutinized using synchrotron X-ray microtomography or conventional optical microscopy. The results showed that the eight Japanese statues were made from Chamaecyparis obtusa, except for the base of one Japanese statue that was made from Cryptomeria japonica. Both species are important conifers in Japan. In contrast, the Chinese statue was made from hardwood, Paulownia sp.
\end{abstract}

Keywords: Synchrotron X-ray microtomography, Japanese statues, Chinese statue, Wood species identification, Museum of Fine Arts, Boston

\section{Introduction}

In Japan, wood identification of wooden statues from the eighth century $\mathrm{AD}$ has been conducted jointly by art historians and wood anatomists. Recently, it was hypothesized that the selection of Torreya nucifera for the eighth-century statues in Japan refers to an ancient sacred text that mentions the usage of wood species for statues. The text mentioned that "Use Santalum spp. for making Buddhist statues, but if you do not have it, use haku." This sacred text might have been brought to Japan with the arrival of the Chinese monk Ganjin in $753 \mathrm{AD}$ (Ch. Jianzhen; 688-763) [1-3]. Santalum spp. was introduced to China from India, and the usage of "haku" was proposed as a substitute of Santalum spp. in China. Furthermore, recent investigations revealed that when this concept of using substitute wood species for statues was introduced to Japan, Torreya nucifera was selected as

\footnotetext{
*Correspondence: tazurusuyako@rish.kyoto-u.ac.jp

1 Laboratory of Biomass Morphogenesis and Information, Research Institute for Sustainable Humanosphere, Kyoto University, Uji, Kyoto 611-0011, Japan

Full list of author information is available at the end of the article
}

"haku". In terms of wood selection, it has been suggested that the species of wood used for statues in neighboring countries of Japan, such as China and Korea, can help reveal the origin and propagation of Buddhist statues.

Many Japanese and Chinese cultural properties of high academic value are stored and managed in museums in Europe and the United States. There are various reasons and circumstances regarding why many of these outstanding cultural assets are located overseas. For example, in Japan, many outstanding Buddhist statues were sold to foreign countries due to historical events, such as the anti-Buddhist movement at the beginning of the Meiji era (haibutsu kishaku), which involved the destruction of Buddhist temples, images, and texts during the Meiji era (1868-1912). Moreover, many of China's excellent Buddhist statues are now displayed in museums in Europe and the United States, and not many remain in China.

Unlike in Japan, few surveys have been conducted on the wood species of these wooden statues in foreign countries. Recently, our group has investigated many outstanding East Asian statues preserved in foreign countries and 
examined the wood species of wooden statues [4-10], and the data on these in East Asian countries are gradually accumulating. Regarding Chinese Buddhist sculptures, wood belonging to the genera Paulownia, Salix, Tilia, Populus, Santalum, Juniperus, and Cupressus are used [4-6]. Thus, although the amount of data remain limited, recently we were able to conduct a survey in the Cleveland Museum of Art of wooden statues from the Tang Dynasty that have not survived in China [11]. We believe that it is important to share these data with researchers in various interdisciplinary fields and those involved in restoration.

In 2019 , we had the valuable opportunity to conduct a survey of the wood species of sculptures from Japan and China stored in the Museum of Fine Arts, Boston. The museum has a large collection of Japanese heritage sculptures. Nowadays many East Asian cultural properties exist in museums in Europe and the United States, which have been studied from an art-historical perspective, but some of those have not been scientifically investigated. Therefore, this project aimed to survey and create a database of these wood species together with cultural properties in Japan.

In this study, we primarily identified wood species of these wood statues using a microscope. However, depending on the degradation state and size of the samples, the synchrotron X-ray microtomography (SRX-ray $\mu \mathrm{CT}$ ) method [12-14] was also applied.

\section{Materials and methods}

In this study, wood identification was performed on 15 samples obtained from eight Japanese sculptures and one Chinese sculpture in the Museum of Fine Arts, Boston, USA (Fig. 1). Wood identification results of Nos. 1-3 have been preliminarily reported [7]. However, since it would be useful for several researchers to study the accumulated results of the survey at the Museum of Fine Arts, the results are listed together here. Regarding the Japanese statues, seven of the eight Japanese Buddha statues were created using the yosegi technique (joined wood block construction). These wooden statues were made from various parts of the wood blocks, and we did not survey all the individual pieces. Indeed, some may have been added during the restoration. However, in this survey, the conservator in the Museum of Fine Arts, Boston, could confirm the original wood and collect the samples. Thus, these concerns can be dispelled to some extent.

The details of the samples are described below:

No. 1 in Table 1, CON428755. Object information for 12.129.1-2 [7].

Amida, the Buddha of Infinite Light.
Japanese, Kamakura period, latter half of the thirteenth century.

Wood with gold and inlaid crystal; joined woodblock construction.

"Special Chinese and Japanese funds.

No. 2 in Table 1, CON437281. Object information for 12.333: [7].

Deva, a Heavenly Being.

Japanese, late Heian period, first half of the eleventh century.

Wood with polychrome and lacquer; single woodblock construction.

"Gift of Francis Gardner Curtis.

No. 3 in Table 1, CON437903. Object information for 36.413: [7].

The Shinto Deity Hachiman in the Guise of a Buddhist Monk.

Japanese, Kamakura period, dated 1328.

Wood with polychrome and inlaid crystal; joined woodblock construction.

"Maria Antoinette Evans Fund and Contributions.

No. 4 in Table 1, CON438001, CON437997. Object information for 50.1948 :

Figure of Guanyin.

Chinese, Song dynasty, 960-1279.

Wood.

"Bequest of Charles Bain Hoyt-Charles Bain Hoyt Collection.

No. 5 in Table 1, SC168748. Object information for 09.73:

Amida, the Buddha of Infinite Light.

Japanese, late Heian period, twelfth century.

Wood with gold; joined woodblock construction.

"Denman Waldo Ross Collection.

No. 6, 7 in Table 1, E9184CR-d1. Object information for 11.10.1-2.

Dainichi, the Buddha of Infinite Illumination.

Japanese, late Heian period, latter half of the eleventh century.

Wood; joined woodblock construction.

"Denman Waldo Ross Collection.

No. 8-10 in Table 1, SC168755. Object information for 11.11409.1-2:

Bishamoten, the Guardian of the North.

Japanese, late Heian period, late eleventh-twelfth century.

Wood with polychrome and gold; joined woodblock construction. 


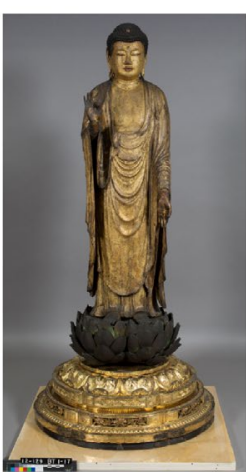

No. 1, 12.129.1-2: Amida, the Buddha of Infinite Light

Japanese, Kamakura period, latter half of the 13th

century

- Special Chinese and

Japanese Fund

Photograph (C) 2020

Museum of Fine Arts,

Boston.

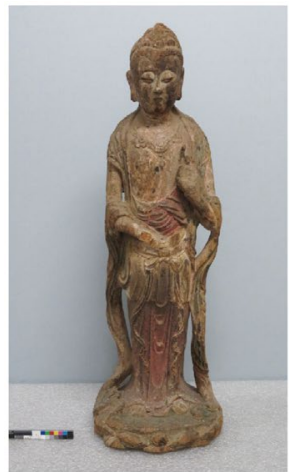

No. 4, 50.1948:

Figure of Guanyin

Chinese, Song dynasty, 960-1279 - Bequest of Charles Bain Hoyt-

Charles Bain Hoyt Collection

Photograph (c) 2020 Museum of

Fine Arts, Boston.

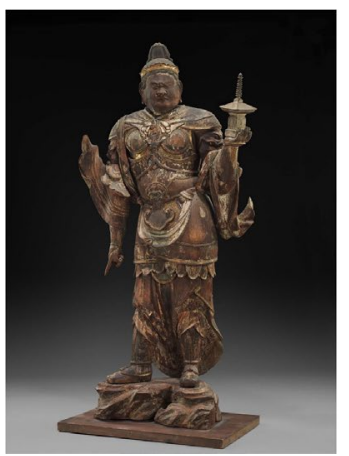

No. 8-10, 11.11409.1-2:

Bishamoten, the Guardian of the North

Japanese, late Heian period, late

11th century-12th century

- William Sturgis Bigelow Collection

Photograph (c) 2020 Museum of Fine Arts, Boston.

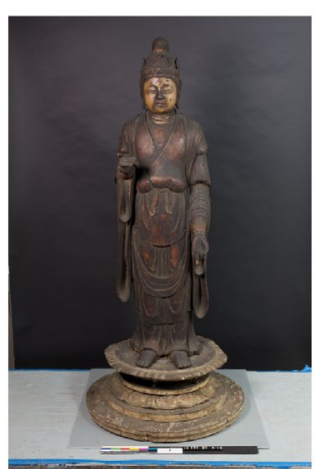

No. 2, 12.333:

Deva, a Heavenly Being Japanese, late Heian period,

first half of the 11th century

- Gift of Francis Gardner Curtis Photograph (C) 2020 Museum of Fine Arts, Boston.

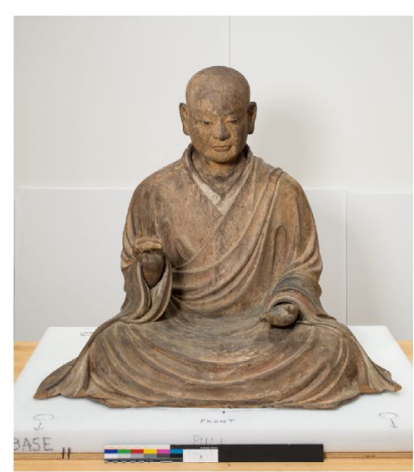

No. 3, 36.413:

The Shinto Deity Hachiman in the Guise of a Buddhist Monk

Japanese, Kamakura period, dated 1328

- Maria Antoinette Evans Fund and

Contributions

Photograph (c) 2020 Museum of Fine Arts, Boston.

Nos. 1-3 has preliminary published.

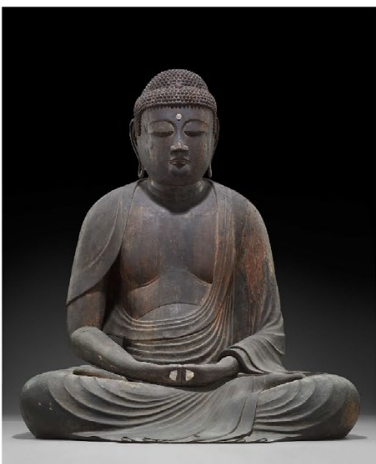

No. $5,09.73$

Amida, the Buddha of Infinite Light

Japanese, late Heian period, 12th century - Denman Waldo Ross Collection Photograph (c) 2020 Museum of Fine Arts, Boston.

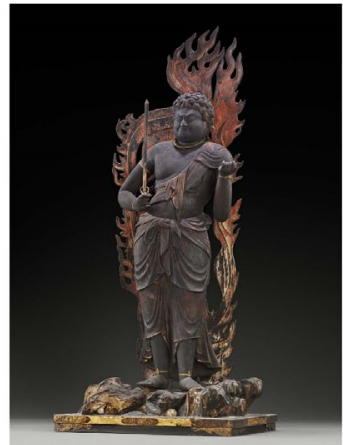

No. $11,12,05.220 .1-3$ :

Fudô myôô, the Immovable One Japanese, late Heian period, 12th century

- Special Chinese and Japanese

$$
\text { Fund }
$$

Photograph (c) 2020 Museum of Fine Arts, Boston.

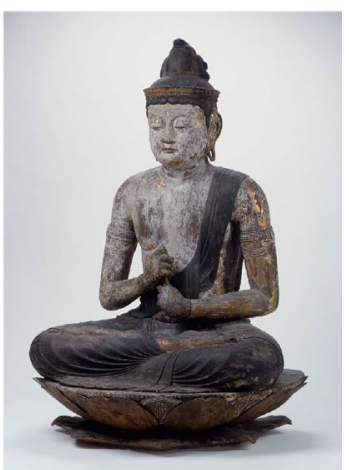

No. $6,7,11.10 .1-2$ :

Dainichi, the Buddha of Infinite Illumination

Japanese, late Heian period, latter half of e 11th century

- Denman Waldo Ross Collection

Photograph (c) 2020 Museum of Fine Arts, Boston.

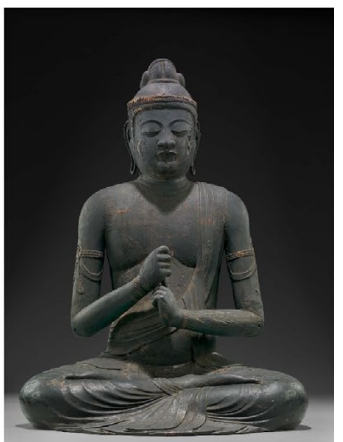

No. $13-15,11.11428$ :

Dainichi, the Buddha of Infinite Illumination

apanese, late Heian period, dated

1105 (Choji 2)

- William Sturgis Bigelow Collection Photograph (C) 2020 Museum of Fine Arts, Boston.

Fig. 1 (See legend on previous page.) 
Table 1 Details and identification results of Japanese and Chinese statues

\begin{tabular}{|c|c|c|c|c|c|c|}
\hline Serial no. & Accession nos. & $\begin{array}{l}\text { Title sort (sample name and } \\
\text { collected part) }\end{array}$ & Culture & Sample size $(\mathrm{mm})$ & Date & Identified species \\
\hline $1^{\mathrm{a}}$ & 12.129 & $\begin{array}{l}\text { Amida, the Buddha of Infinite } \\
\text { Light (base) }\end{array}$ & Japan & $<0.5 \times 1 \times 2$ & $\begin{array}{l}\text { Kamakura period, latter half of } \\
\text { the thirteenth century }\end{array}$ & Chamaecyparis obtusa \\
\hline $2^{\mathrm{a}}$ & 12.333 & $\begin{array}{l}\text { Deva, a Heavenly Being (under- } \\
\text { side, centerback) }\end{array}$ & Japan & $<1 \times 1 \times 2$ & $\begin{array}{l}\text { Late Heian period, first half of } \\
\text { the eleventh century }\end{array}$ & Chamaecyparis obtusa \\
\hline $3^{\mathrm{a}}$ & 36.413 & $\begin{array}{l}\text { The Shinto Deity Hachiman in } \\
\text { the Guise of a Buddhist Monk } \\
\text { (inside of neck cavity) }\end{array}$ & Japan & $<0.5 \times 1 \times 2$ & Kamakura period, dated 1328 & Chamaecyparis obtusa \\
\hline 4 & 50.1948 & $\begin{array}{l}\text { Figure of Guanyin (underside } \\
\text { and back edge) }\end{array}$ & China & $<1 \times 2 \times 2$ & Song dynasty & Paulownia sp. \\
\hline 5 & 09.73 & $\begin{array}{l}\text { Amida, the Buddha of Infinite } \\
\text { Light, (lower back) }\end{array}$ & Japan & $1 \times 2 \times 5$ & $\begin{array}{l}\text { Late Heian period, the twelfth } \\
\text { century }\end{array}$ & Chamaecyparis obtusa \\
\hline 6 & 11.10 .1 & $\begin{array}{l}\text { Dainichi, the Buddha of Infinite } \\
\text { Illumination, [mortise in back } \\
\text { (PR)] }\end{array}$ & Japan & $1 \times 2 \times 4$ & $\begin{array}{l}\text { Late Heian period, latter half of } \\
\text { the eleventh century }\end{array}$ & Chamaecyparis obtusa \\
\hline 7 & 11.10 .2 & $\begin{array}{l}\text { Dainichi, the Buddha of Infinite } \\
\text { Illumination, [Daiza, back lotus } \\
\text { petal }(P L)]\end{array}$ & Japan & $0.5 \times 1 \times 6$ & $\begin{array}{l}\text { Late Heian period, latter half of } \\
\text { the eleventh century }\end{array}$ & Chamaecyparis obtusa \\
\hline 8 & 11.11409.1.1 & $\begin{array}{l}\text { Bishamoten, the Guardian of the } \\
\text { North, (tenon, PR foot) }\end{array}$ & Japan & $1 \times 3 \times 4$ & $\begin{array}{l}\text { Late Heian period, late eleventh } \\
\text { century-twelfth century }\end{array}$ & Chamaecyparis obtusa \\
\hline 9 & 11.11409.1.1 & $\begin{array}{l}\text { Bishamoten, the Guardian of the } \\
\text { North, [drapey sleeve (PR)] }\end{array}$ & Japan & $2 \times 2 \times 10$ & $\begin{array}{l}\text { Late Heian period, late eleventh } \\
\text { century-twelfth century }\end{array}$ & Chamaecyparis obtusa \\
\hline 10 & 11.11409 .2 & $\begin{array}{l}\text { Bishamoten, the Guardian of the } \\
\text { North, [bottom edge or base, } \\
\text { back (PL)] }\end{array}$ & Japan & $1 \times 2 \times 3$ & $\begin{array}{l}\text { Late Heian period, late eleventh } \\
\text { century-twelfth century }\end{array}$ & Chamaecyparis obtusa \\
\hline 11 & 05.220 .3 & $\begin{array}{l}\text { Fudô myôô, the Immovable } \\
\text { One, [under bottom edge (PR)] }\end{array}$ & Japan & $1 \times 2 \times 3$ & $\begin{array}{l}\text { Late Heian period, the twelfth } \\
\text { century }\end{array}$ & Chamaecyparis obtusa \\
\hline 12 & 05.220 .2 & $\begin{array}{l}\text { Fudô myôô, the Immovable } \\
\text { One, (base, inside PL mortise) }\end{array}$ & Japan & $1 \times 2 \times 5$ & $\begin{array}{l}\text { Late Heian period, the twelfth } \\
\text { century }\end{array}$ & Cryptomeria japonica \\
\hline 13 & 11.11428 & $\begin{array}{l}\text { Dainichi, the Buddha of Infinite } \\
\text { Illumination, (inside, Interior) }\end{array}$ & Japan & $0.5 \times 2 \times 12$ & $\begin{array}{l}\text { Late Heian period, dated } 1105 \\
\text { (Choji 2) }\end{array}$ & Chamaecyparis obtusa \\
\hline 14 & 11.11428 & $\begin{array}{l}\text { Dainichi, the Buddha of Infinite } \\
\text { Illumination, (PL) }\end{array}$ & Japan & $0.5 \times 4 \times 13$ & $\begin{array}{l}\text { Late Heian period, dated } 1105 \\
\text { (Choji 2) }\end{array}$ & Chamaecyparis obtusa \\
\hline 15 & 11.11428 & $\begin{array}{l}\text { Dainichi, the Buddha of Infinite } \\
\text { Illumination, (interior head } \\
\text { front) }\end{array}$ & Japan & $0.5 \times 1 \times 7$ & $\begin{array}{l}\text { Late Heian period, dated } 1105 \\
\text { (Choji 2) }\end{array}$ & Chamaecyparis obtusa \\
\hline
\end{tabular}

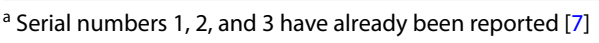

$P L$ proper left; $P R$ proper right

*William Sturgis Bigelow Collection.

No. 11, 12 in Table 1, SC168744. Object information for 05.220.1-3:

Fudô myôô, the Immovable One.

Japanese, late Heian period, twelfth century.

Wood with polychrome and gold; joined woodblock construction.

*Special Chinese and Japanese funds.

No. 13-15 in Table 1, SC168757. Object information for 11.11428:

Dainichi, the Buddha of Infinite Illumination.

Japanese, late Heian period, dated 1105 (Choji 2).

Wood with gold; split-and-joined construction.

*William Sturgis Bigelow Collection.
Samples shaped and sized like the tip of a toothpick were carefully taken from cracks and naturally occurring hollowing on the underside of the sculptures with the consultation of the curators and conservators, without harming the surface and appearance of statues. The details of the samples are listed in Table 1. Each preparation for the identification of wood samples was conducted at RISH, Kyoto University, Japan. Most of the samples were soaked in water for softening. To prepare the microscopic slides, thin sections were taken using razor blades from transverse, radial, and tangential surfaces (approximately 15-30 $\mu \mathrm{m}$ thick). The sections were placed on glass slides and mounted in a mixture of ethanol and glycerol. The sections on the glass slides 
were heated on a hot plate at a temperature higher than $100{ }^{\circ} \mathrm{C}$ to remove air bubbles from the wood sections. After heating, the sections were rinsed with fresh water and mounted in mounting media containing a mixture of Arabic gum and chloral hydrate.

The slides were examined under an optical microscope (Olympus model BX51, Japan), and each micrograph was captured using a digital camera (Olympus model DP70, Japan).

Four samples (Nos. 1-4) of the 15 samples were too small and brittle for microscopic preparation. To obtain inner microstructural images safely from these tiny and fragile samples, SRX-ray $\mu \mathrm{CT}$ was applied on the beamline 20XU at SPring-8, Hyogo Prefecture, Japan. Wood samples with a height of $5 \mathrm{~mm}$ and a diameter of $0.7 \mathrm{~mm}$ were fixed on the cylindrical stick. The sample was scanned with a rotation of $0.1^{\circ}$, and 1800 projections were acquired using a CCD camera. The resolution of the images was $0.472 \mu \mathrm{m} /$ pixel. Slide images were then reconstituted using the free software Image J.

Through image processing with Image J software, pseudo-sections were obtained in transverse, radial, and tangential directions, which are necessary for wood identification. Each original reconstituted slice made by SRX-ray $\mu C T$ was approximately $0.472 \mu \mathrm{m}$ thick. Therefore, it was necessary to increase the depth information to avoid losing anatomical information. Thus, 24 slices were merged, and approximately $12-\mu \mathrm{m}$-thick pseudomicrographs were obtained. Wood identification was conducted with these reconstructed pseudo-sections using references from previous publications $[15,16]$. For identification, we also referred to the Wood Diversity HSDB network (http://database.rish.kyoto-u.ac.jp/arch/ bmi/Xylarium_net/cai_jiandetabesu.html).

\section{Results}

In addition to the results of Nos. 1-3 that have been previously reported [7], our investigation showed that the samples Nos. 1-3, 5-11, and 13-15 were revealed to be Chamaecyparis obtusa, and No. 12 was Cryptomeria japonica. The Chinese statue (No. 4) was revealed to be Paulownia sp.

Table 1 also includes information on Nos. 1-3. Pseudosections constructed from the SRX-ray $\mu \mathrm{CT}$ dataset from SPring- 8 and micrographs for each sample are presented in Fig. 2 (Nos. 1-3 are not included in Fig. 2).

The basis of the above identification is as given below.

\section{Chamaecyparis obtusa (Nos. 1-3, 5-11, and 13-15)}

The growth ring boundaries were distinct. The transition from earlywood to latewood was gradual. Resin canals were absent, and resin cell was present. The ray height was 3-9 cells, and the ray width was exclusively uni-seriate. Nos. 1-3, 5-11, and 13-15 had piceoid to cupressoid pits with circular borders that occurred around 2 per a cross-field (Fig. 2). Mostly, cross-field pits occurred in the vertical center of cross-fields. The most of the apertures of cross-field pits opened diagonally to vertically. Recently, wood anatomical differences of Japanese species of Cupressaceae were studied to evaluate the possibility of identifying these species [17]. The anatomical features of Nos. 1-3, 5-11, and 13-15 described above were consistent with those of Chamaecyparis obtusa described in the paper above [17]. Thus they were identified as Ch. obtusa.

\section{Cryptomeria japonica (No. 12)}

Generally, the transition from earlywood to latewood is abrupt, but the transverse section of No. 12 contains no ring boundaries (Fig. 2), so it was difficult to confirm. Resin canals were absent. Ray height was $3-5$ cells, and ray width was exclusively uni-seriate. The cross-fieldpitting type was taxodioid. The number of pits per crossfield was approximately $2-3$. Based on these anatomical features, No. 12 was identified as C. japonica.

\section{Paulownia sp. (No. 4)}

The growth ring boundaries could not be observed in No. 4 , so it was difficult to obtain information (Fig. 2). Pores were solitary, sometimes in multiples of 2 , with an angular outline. The tangential diameters of the vessels were approximately $100 \mu \mathrm{m}$ in the transverse section. The perforation plates were simple. Rays were nearly homogeneous and were $2-4$ cells wide and 5-10 cells high. The rays were angular and arrow-shaped. Both ends of each ray had a tapered shape. The walls of the constituent cells were relatively thin. Based on these anatomical features, No. 4 was identified as a Paulownia sp.

\section{Discussion}

Wood identification of the Japanese and Chinese Buddhist statues owned by the Museum of Fine Arts, Boston, was conducted. Fifteen samples obtained from eight Japanese and one Chinese wooden sculpture were investigated. Of the Japanese samples, 13 were made of Ch. obtusa, and one (the base of the statue) of C. japonica. The Chinese sample was identified as Paulownia sp. Namely, all eight statues from Japan were made of $C h$. obtusa, whereas the one from China was made of Paulownia sp.

Generally, the research conducted by Jiro Kohara [18] and others, including the Tokyo National Museum and Forest Research and Management Organization, has revealed that the materials used for Buddhist statues in Japan have changed over time. For example, in the sixth century, just after the arrival of Buddhism, "Houkei 
(Naki) Maitreya" in Koryuji Temple in Kyoto city was scientifically revealed to be made of Cinnamomum camphora (L.) J. Presl. [19]. However, in the eighth century, with the introduction of danzo (sandalwood sculpture) from India via China, wood species for statues were drastically changed to T. nucifera in Japan. Although there are exceptions, mainstream species for statues were coniferous.
Regarding the style of Japanese sculpture, previous studies of wood species in wooden Buddhist statues have suggested that from the eighth century onward, most of the single-block statues were made from $T$. nucifera. However, with the gradual introduction of the yosegi technique from the mid-Heian period, the number of statues made of Ch. obtusa began to increase. Although there are many wooden statues made from T. nucifera in
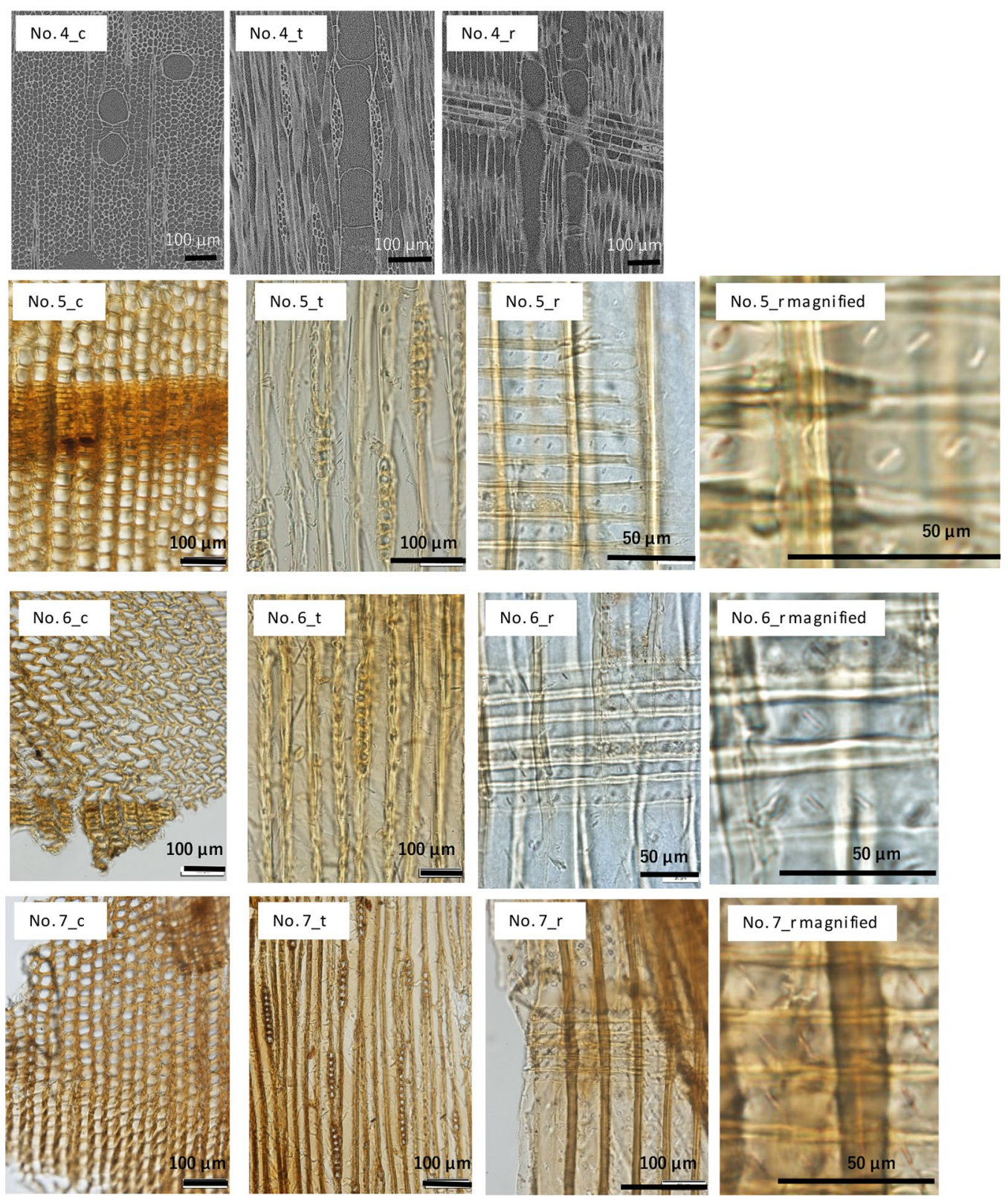

Fig. 2 Pseudo-sections of Nos. 4_c, 4_t, and 4_r and micrographs for each sample (5-15). The pseudo-sections are constructed from the SRX-ray HCT dataset from SPring-8. Wood identification results of Nos. 1-3 have already published in the previous report [7]. Therefore, they were omitted here 

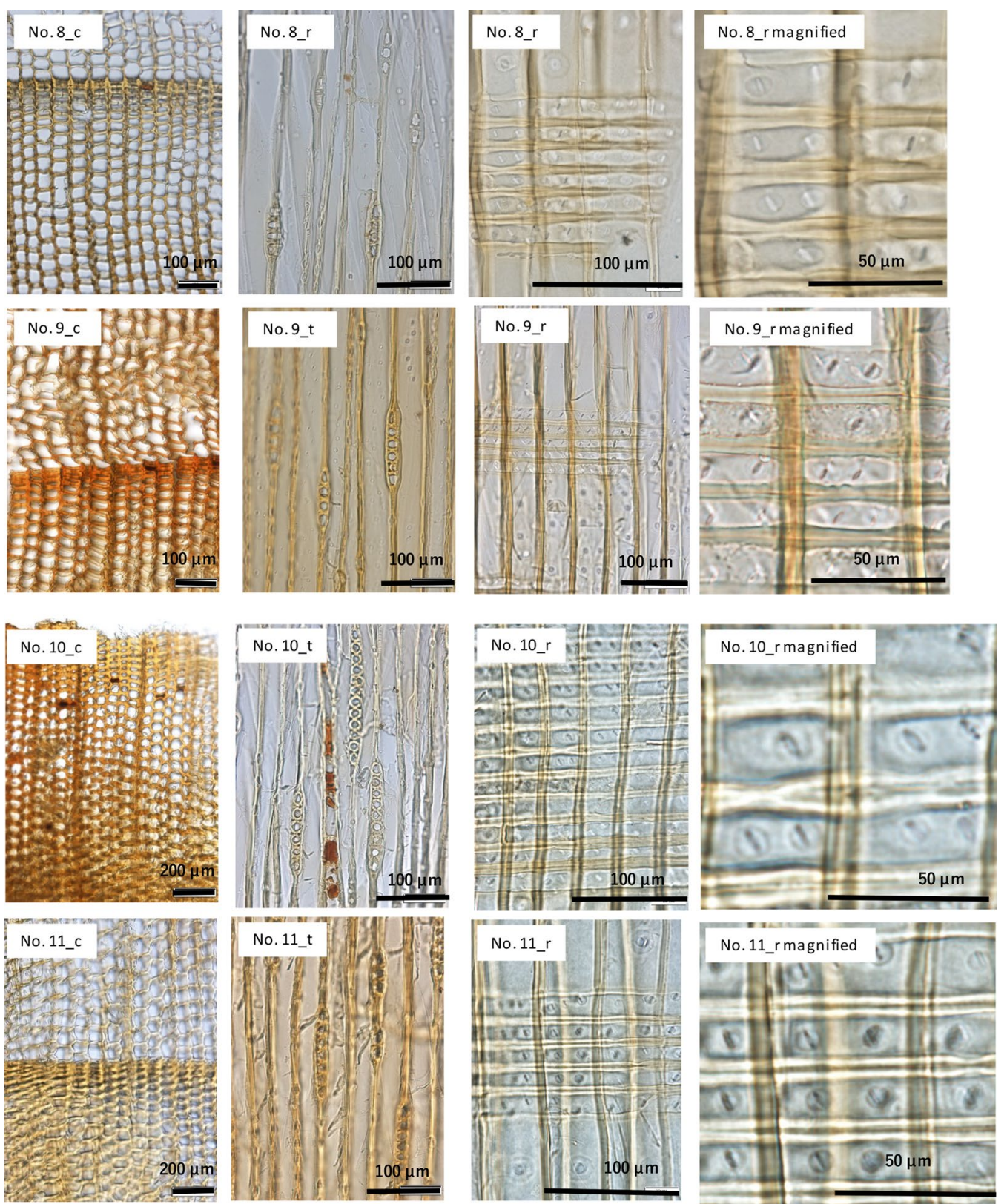

Fig. 2 continued 

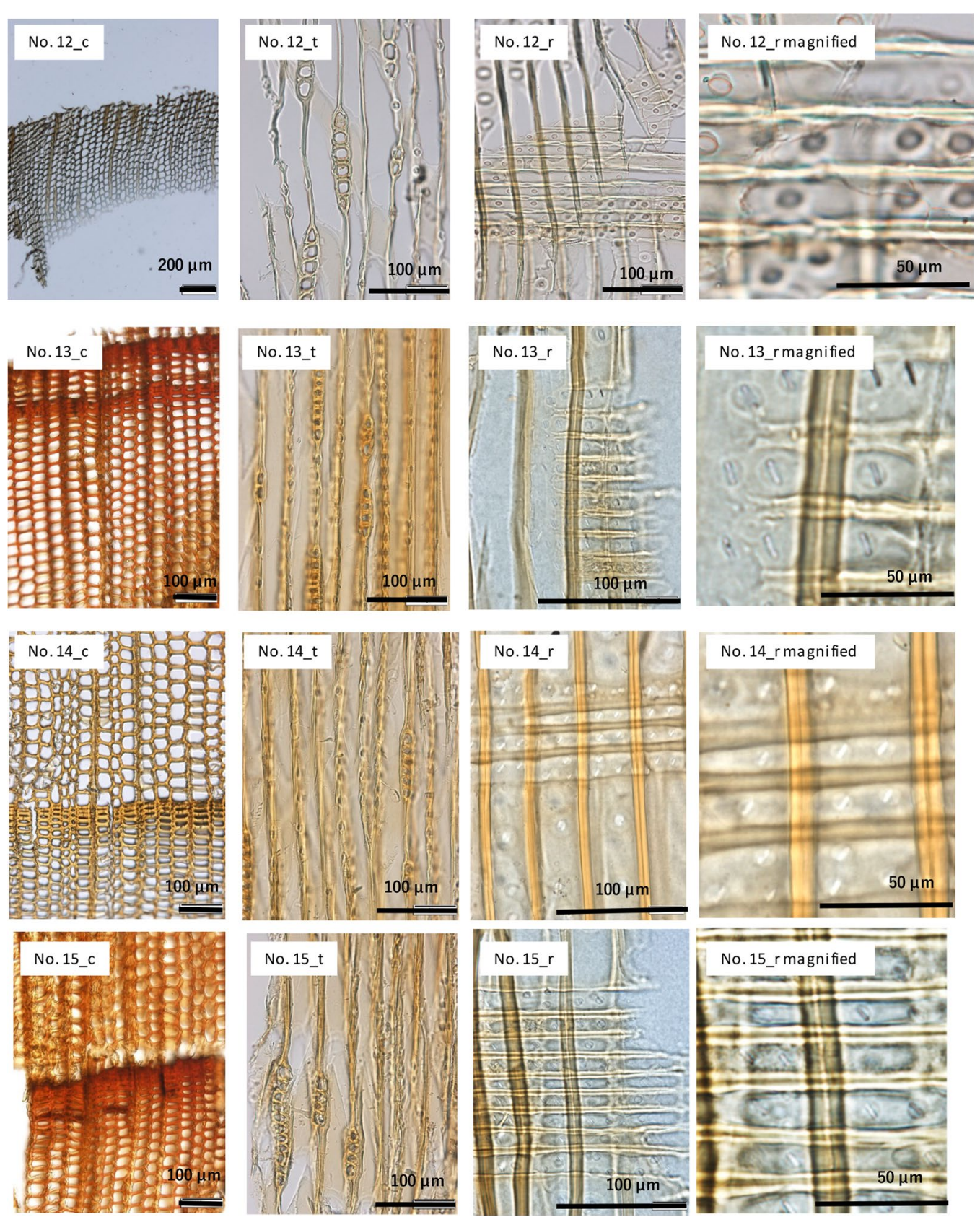

Fig. 2 continued

the Heian period, T. nucifera tends to be used more in single-block sculptures. From this perspective, the fact that most of the Japanese Buddhist statues we surveyed in the Museum of Fine Arts, Boston, were made of $\mathrm{Ch}$. obtusa is an important finding when considering their age.

One statue from China was made from Paulownia sp. Previous research on over 60 Chinese wooden statues preserved in several US museums [4-7] identified the following wood species using a microscope: Paulownia spp. (17 statues), Tilia spp. (16 statues), Salix spp. (15 statues), and Populus spp. (3 statues). Among these statues, most of the Buddhist statues made of Paulownia spp. were thought to be made between the tenth to thirteenth centuries. The Chinese statue in the Museum of Fine Arts identified in this survey was assumed to be 
made in the same period above, namely Song dynasty by the sculpture style, which is consistent with our previous data.

Unlike in China, in Japan, wood belonging to the genus Paulownia is rarely used for Buddhist statues. For instance, only two statues in Yatadera temple and one statue in the Tōshōdaiji temple in Nara Prefecture have been identified as Paulownia spp. [20]. We do not have enough information to explain why wood of Paulownia spp. was often used in Chinese statues.

\section{Conclusion}

Wood identification of Japanese and Chinese Buddhist statues owned by the Museum of Fine Arts, Boston, USA, was conducted. From the eight Japanese wood sculptures and one Chinese sculpture, 15 samples were collected. All Japanese statues were made of Ch. obtusa, one sample from the base of a Japanese statue was made of $C$. japon$i c a$, and one Chinese statue was made of Paulownia sp.

Recent research has revealed that the species of trees used for wooden Buddhist statues in Japan differ from those in China, the country that introduced Buddhism to Japan, but the reasons for this difference have not yet been elucidated. However, the finding that Japanese wood sculpture from the tenth century AD onward made extensive use of Ch. obtusa is an important piece of information that will help us determine the style and date of sculptures. The use of C. japonica for the pedestal is also an important finding for understanding the origin of the Buddha statue, since $C$. japonica is endemic to Japan. The single Buddha image from China was identified as Paulownia sp. Unlike in Japan, our previous research has revealed that many Chinese statues are made of Paulownia spp.

In Japan, wood of Paulownia spp. was used for furniture, koto (13-stringed Japanese zither), boxes, and geta (wooden clogs), while in China, it was also often used for sculptures. To understand each country's criteria of wood use for Buddhist statues, it is necessary to conduct a continuous survey of the remaining Chinese Buddhist statues in Europe and the United States.

This paper only reports the results of wood identification of Japanese and Chinese wooden Buddhist statues stored in the Museum of Fine Arts, Boston, with some discussion. However, we have decided to publish all these data together because we believe that it is important to share them with researchers in various interdisciplinary fields. At present, important cultural assets from Japan [21-23] and China (as observed on each museum's website) are carefully stored overseas, and we hope that building cooperative relationships can lead to the discovery of Buddhist statues with a new meaning in Asian Buddhist art. Continued research is needed to study the species used to make Buddhist statues in China in the seventh and eighth centuries and understand the significance of haku written in ancient books in Asian countries. Finally, we would like to continue the research without ever forgetting the ethical perspective in cultural property research. We hope that this study will highlight the study of East Asian wooden statues, and we will continue our research in the future.

\section{Abbreviations \\ SRX-ray $\mu C T$ : Synchrotron X-ray microtomography.}

\section{Acknowledgements}

This work was supported by JSPS KAKENHI Grant Number 19K01124, obtained by Suyako Tazuru. Part of this study was supported by the Database for the Humanosphere of RISH, Kyoto University, as a collaborative program. We are indebted to Abigail Hykin (Conservator of Museum of Fine Arts, Boston) and her colleagues for providing the opportunity to investigate wood sculptures and for their kind cooperation and suggestions. The synchrotron radiation experiments were performed at beamline 20XU at SPring-8 (Japan) with the approval of the Japan Synchrotron Radiation Research Institute (JASRI) (Proposal No. 2018B1747). This work was also supported by Grants-in-Aid for Scientific Research from JSPS (19K01124) and mission-linked research (mission 5-4) from RISH, Kyoto University. The wood identification results of the Buddhist sculpture of Amida (12.129.1-2), the Deva statue (12.333), and the Shinto deity Hachiman in the Guise of a Buddhist monk (36.413) were preliminarily presented in the Spring-8/SACLA Research Reports, Vol. 8, No. 3, 2020.

\section{Authors' contributions}

$\mathrm{ST}, \mathrm{MM}, \mathrm{TI}$, and JS have participated sufficiently in wood identification and bear full responsibility for this content. All authors have read and approved the final manuscript.

\section{Funding}

This work was supported in part by Grants from the Japan Society for the Promotion of Science (KAKENHI, 19 K01124 obtained by Suyako Tazuru) and RISH, Kyoto University (Mission-linked Research Funding, \#2018-5-4-1, \#2019-5-4-1, and \#2020-5-4-1).

Availability of data and materials

All data analyzed during this study are included in this published article.

\section{Declarations}

\section{Competing interests}

The authors declare that they have no competing interests.

\section{Author details}

${ }^{1}$ Laboratory of Biomass Morphogenesis and Information, Research Institute for Sustainable Humanosphere, Kyoto University, Uji, Kyoto 611-0011, Japan. ${ }^{2}$ East Asian Civilisations Research Centre CRCAO-CNRS, Paris, France. ${ }^{3}$ Nara National Research Institute for Cultural Properties, Nara, Japan. ${ }^{4}$ Faculty/Graduate School of Agriculture, Kyoto University, Sakyo-ku, Kyoto 606-8502, Japan. ${ }^{5}$ College of Materials Science and Engineering, Nanjing Forestry University, Nanjing, China.

Received: 4 October 2021 Accepted: 14 February 2022

Published online: 03 March 2022

\section{References}

1. Kaneko H, Iwasa M, Noshiro S, Fujii T (1998) Wood types and material selection for Japanese wooden statues of the ancient period particularly the 7th-8th century. Museum 555:3-54 
2. Kaneko H, Iwasa M, Noshiro S, Fujii T (2003) Wood types and material selection for Japanese wooden statues of the ancient period (particularly of the 8th-9th centuries). Museum 583:5-44

3. Kaneko H, Iwasa M, Noshiro S, Fujii T (2010) Wood types and material selection for Japanese wooden statues of the ancient period, III: further thoughts on 8th- and 9th-century sculptures. Museum 625:61-78

4. Mertz M, Itoh T (2010) Analysis of wood species in the collection, wisdom embodied —Chinese Buddhist and Daoist sculpture in the Metropolitan Museum of Art. Yale University Press, New Haven and London, pp 216-225

5. Tazuru-Mizuno S (2021) Wood selection for Chinese wood statues preserved in the several museums in the USA. Seizonken Kenkyu 17:58-60

6. Tazuru S, Mertz M, Kinoshita H, Itoh T, Sugiyama J (2021) Wood identification of Chinese Buddhist statues in the Philadelphia Museum of Art. Sci Stud Cult Prop 83:107-117

7. Tazuru S, Mertz M (2021) Case study of wood identification of Japanese wood statues owned by the Museum of Fine Arts, Boston, USA. Spring-8/SACLA research report, vol 8. Springer, Berlin, pp 506-508

8. Mertz M, Itoh T (2007) The study of Buddhist sculptures from Japan and China, based on wood identification. In: Douglas JG, Jett P, Winter $J$ (eds) Scientific research on the sculptural arts of Asia Proceedings of the third Forbes symposium at the Freer Gallery of Art. Smithsonian Institution, Washington, pp 198-204

9. Mertz M, Itoh T (2008) Identification des bois de huit sculptures Chinoises et de deux sculptures Japonaises conserves aux Muses Royaux d'art et d'histoire de Bruxelles. Bull Musees Royaux Art Hist Parc Cinquantenaire Brux 76(127-148):217-224

10. Mertz M, Itoh T (2010) A study of the wood species of 73 deity sculptures of the Hunan Province, from the Patrice Fava Collection. Asie 19:183-214. https://doi.org/10.3406/asie.2010.1352

11. Tazuru S, Mertz M (2021) Case study of the wood identification of a Chinese eleven-headed Guanyin Owned by the Cleveland Museum of Art. Spring-8/SACLA research report, vol 9. Springer, Berlin, pp 524-526

12. Mizuno S, Torizu R, Sugiyama J (2010) Wood identification of a wooden mask using synchrotron X-ray microtomography. J Archaeol Sci 37:28422845. https://doi.org/10.1016/j.jas.2010.06.022

13. Hwang SW, Tazuru S, Sugiyama J (2020) wood identification of a historical architecture in Korea by synchrotron X-ray microtomography based three-dimensional microstructural Imaging. J Korean Wood Sci Technol 48:283-290

14. Tazuru-Mizuno S, Sugiyama J (2019) Wood identification of Japanese Shinto deity statues in Matsunoo-taisha Shrine in Kyoto by synchrotron $X$-ray microtomography and conventional microscopy methods. J Wood Sci 65:60. https://doi.org/10.1186/s10086-019-1840-2

15. Wheeler EA, Baas P, Gasson PE (1989) IAWA list of microscopic features for hardwood identification. IAWA Bull NS 10:219-332

16. Richter HG, Grosser D, Heinz I, Gasson PE (2004) IAWA list of microscopic features for softwood identification. IAWA J 25:1-70. https://doi.org/10. 1163/22941932-90000349

17. Shuichi N (2011) Identification of Japanese species of Cupressaceae from wood structure. Jpn J Histor Bot 19(1-2):125-132. https://doi.org/10. 34596/hisbot.19.1-2_125

18. Kohara J (1972) Kinobunka. Kashima syuppankai, Tokyo, pp 31-114

19. Kaneko H, Noshiro S, Abe H, Fujii T, Iwasa M (2019) Reexamination of "Samples formerly owned by Kohara Jiro for a material study of wooden sculptures." Museum 679:5-60

20. Itoh T, Sano Y, Abe H, Utsumi Y, Yamaguchi K (2011) Useful trees of Japan: a color guide. Kaiseisya, Otsu, pp 80-83

21. Shimizu Z (1979) Japanese sculptures in America and Canada (1). Ars Buddhica 126:67-88

22. Shimizu Z (1979) Japanese sculptures in America and Canada (2). Ars Buddhica 127:88-116

23. Shimizu Z (1980) Japanese sculptures in America and Canada (3). Ars Buddhica 128:98-117

\section{Publisher's Note}

Springer Nature remains neutral with regard to jurisdictional claims in published maps and institutional affiliations.

\section{Submit your manuscript to a SpringerOpen ${ }^{\circ}$ journal and benefit from:}

- Convenient online submission

- Rigorous peer review

- Open access: articles freely available online

- High visibility within the field

- Retaining the copyright to your article

Submit your next manuscript at $\boldsymbol{\nabla}$ springeropen.com 